Teknokultura. Revista de Cultura Digital y Movimientos Sociales

ISSNe: $1549-2230$

http://dx.doi.org/10.5209/tekn.6693

\title{
Tech power: a critical approach to digital corporations
}

\author{
Aitor Jiménez González ${ }^{1}$
}

Recibido: 9 de diciembre 2019 / Aceptado: 25 de enero 2020 Open peer reviews

\begin{abstract}
This article explores different bodies of literature looking at the rising power of digital corporations. With this work I aim to provide a critical up-to-date approach to the topic. The first part of the paper introduces the phenomenon of digital capitalism, navigating different sociological approaches. Then, it proceeds by addressing the difficulties of naming the phenomenon and the attention that is gathering among politicians, academics and the general public. The second part of the work explores three different but complementary bodies of literature looking at tech power In the first place the paper explores critical management studies' contributions describing the characteristics of digital corporations. Secondly, the text reflects critical legal scholars' works analysing what has been identified as one of the essential features of digital capitalism: the infrastructural power enjoyed by corporations such as Facebook or Amazon. Finally the paper exposes two different Marxist perspectives looking at digital capitalism and its latest developments. The labour-focused Marxist contribution mainly represented by Christian Fuchs and Trebor Scholz and the postfordist approach of Maurizio Lazzarato or Matteo Pasquinelli, among others.
\end{abstract}

Keywords: digital capitalism; digital Marxism; infrastructural power; Silicon Valley

\section{[es] Poder tecnológico: un acercamiento crítico a las corporaciones digitales}

Resumen. Este artículo explora diferentes cuerpos de literatura centrados en el análisis del auge del poder de las corporaciones digitales. Con esta obra se pretende proporcionar un actualizado estado del arte sobre el poder corporativo digital, así como ofrecer un bosquejo multidisciplinario y crítico de sus complejidades. La primera parte de la obra presenta el fenómeno del capitalismo digital, navegando diferentes enfoques sociológicos. Luego procede abordando las dificultades de nombrar el evento, así como la atención que está recabando entre políticos, académicos y el público en general. La segunda parte del trabajo explora tres cuerpos de literatura analizando el capitalismo digital, diversos pero complementarios. En primer lugar, el artículo explora diferentes aproximaciones desde los Critical Management Studies, las cuáles describen las características principales de las corporaciones digitales. En segundo lugar, el texto refleja trabajos provenientes delos Critical Legal Studies, enfoque que ha situado como una de las características esenciales del capitalismo digital el denominado como 'Infrastructural Power' ejercido por corporaciones como Facebook o Amazon. Finalmente, el artículo expone dos perspectivas marxistas diferentes analizando los últimos desarrollos del capitalismo digital. La contribución marxista centrada en la cuestión del trabajo representada principalmente por Christian Fuchs y Trebor Scholz y el enfoque posfordista de Maurizio Lazzarato o Matteo Pasquinelli, entre otros.

Palabras clave: capitalismo digital; marxismo digital, poder infraestructural; Silicon Valley.

Summary. 1. Introduction. 2. Names. 3. The critical management perspective: what is new in the new digital corporations? 4. Critical legal studies and the infrastructural power. 5. Digital communism: socialist and postfordists. 6. Conclusions. 7. References.

Cómo citar: Jiménez González, A. (2020). Tech power: a critical approach to digital corporations. Teknokultura. Revista de Cultura Digital y Movimientos Sociales, 17(1), 77-85.

\section{Introduction}

The rise of digital capitalism has revolutionised relations of production, financial markets, retail business, and communications (Janeway, 2018; Johannesen, 2019). It is also transforming real estate, tourism, industrial and even agricultural production (Carolan, 2019; de Graaf, 2017). The 'advantages' of such transformation are obvious. Information and know-ledge have never been so accessible for the many. The cost of communication has been halved in a matter of five years. Formerly sci-fi Artificial Intelligence (AI) technologies are now available in almost every new dispositive, allowing a radical transformation on how we understand efficiency and resource management, the decentralisation of production or the organisation of work and the role of workers in the job market (Braña, 2019).

However, the protagonists of this transformation are a handful of extraordinarily powerful companies dominating the market and enjoying a de-facto monopolistic situation in fields as different as online commerce, communications, clouding services, ad- 
vertising, operating systems or internet search, among others (van Dijck, Nieborg \& Poell, 2019). Facebook and its proxies controls the communications of nearly 4.1 Billion people, a power never achieved by any other telecommunication company (Vaidhyanathan, 2018). Google is the main gate to the Internet (and for many its epitome), controlling half of the worldwide searches. Alphabet (Google's owner) has also heavily invested in IA, venture capital, robotics and, above all, software. Its portable Operation System (OS) Android is enjoying a prominent position of privilege, for some a virtual monopoly, as its present in $80 \%$ of the smartphones (Moore \& Tambini, 2018). Amazon is not only the undisputed online retail provider for everything, its strategy comprehends digital analogic logistic. Its clouding services have become the solid infrastructure where other online platforms, such as Netflix, rely (Wingfield, 2017). As Rosenblat (2018) claims, Uber, has not only become an important actor in the transportation industry, its influence goes further. Its conception of labour is disrupting global markets, academia and governments, to the extent that the binomial notion of dependant or non-dependant worker has become suddenly obsolete. Airb$\mathrm{nb}$ offers today more beds than any other hospitality chain. As successful as controversial, it has been at the epicentre of relevant political discussions in cities such as New York, Paris, Barcelona, San Francisco or Venice. Its business model has made necessary the re-evaluation of policies such as zoning different urban areas and the taxation of emergent business models (Brossat, 2018; Gil \& Sequera, 2018).

But not only traditional industries have suffered the radical mutation. Love, friendship, influence, family, personal communications, curiosity, the care of the self, that is, the formerly aspects of life that used to remain outside the mercantilisation processes, are slowly being commodified, datafied, by extractive 'capitalist platforms' such as Facebook, Tinder or Instagram (Palmer, 2020; Hobbs, Owen, \& Gerber, 2017; Thatcher, 2017; Rouvroy \& Stiegler, 2016). As it has been pointed out by Castells (2010) and more recently by Couldry and Mejias (2019), culture, information, and knowledge are at the core of the digital and informational economy inasmuch as at the heart of the so called digital imperialism. Digital corporations control a disproportionate rate of the information that reaches Global North citizens, this has been pointed out not only by academics such as Moore and Tambini (2018) but also by the EU Commission (Klossa, 2019) or the French Government (Thieulin, 2019). This position of control between users, users' private data and users' access to information has its value, not only in terms of its monetary equivalent but as a means of political power. To mention one example for many users, Facebook is more than a 'bio narrative', it is the place where political discussion happens. It is the place where opinions on candidates take form. The electoral machinery, and therefore the parties' apparatuses, have been forced to adapt to this new reality of fragmented audiences, personalized ads, and an unprecedented availability of data about potential voters (Nickerson \& Rogers, 2014). Facebook, the biggest and most widely used social network, allowed Cambridge Analytica, a political consultancy company, to harvest data from more than 50 million Americans. Valuable information that many believe gave Donald Trump a decisive push in the presidential elections of 2016 (Grassegger \& Krogerus, 2017).

That Digital platforms represent a threat to democracy is no longer a radical claim. On February 19th 2019, the UK parliament released a report on Disinformation and 'fake news' (UK Parliament, 2019). There, Facebook was described as a digital gangster for its corporate behaviour. In July 2019 a bipartisan commission of the US congress questioned some of the biggest tech companies for their market power and bias as gatekeepers of communication. This is a major investigation working in tandem with other federal agencies that might end in the breakout of Facebook or Google (US House of Representatives, 2019). Likewise, the UE institutions have been involved in an increasing number of litigations with, among others, Google, Uber or Facebook.

\section{Names}

Academics with different sensibilities and from different disciplines acknowledge the magnitude of the cultural, political,economicand social transformation consequence of the digital revolution. However this consensus ends at the time of naming, and with it, interpreting the event. Naming, branding, defining facts and concepts are, without a doubt, a first-class political act determining how the audience perceive reality. In this way, the cluster of economic relations originated (or holding close ties with) in the digital world, has been denominated as 'digital economy', 'platform economy', 'collaborative economy', 'sharing economy', 'crowded capitalism', 'surveillance capitalism', 'platform capitalism' or 'digital capitalism' among many other names (Slee, 2017; Sundararajan, 2014; Srnicek, 2017a, 2017b; Zuboff, 2018). Each of these definitions holds a unique interpretation on how the technological and economic transformations are causing undeniable systemic changes and how this is reshaping the global social structures.

The concept of 'digital economy' has become the preferred option by political institution such as the European Union or its Member States. Some authors (with more passion than science) have been inclined for the concepts of 'sharing' or 'collaborative economy' (Corcho, 2017; Domenech, 2015; Sundararajan, 2016). Following with that we can find what Morozov (2013) has defined as the solutionist Silicon Valley's narrative. For these authors the "collaborative or sharing economy' is the vivid expression of a conscious and humanist version of capitalism. That is, capitalism with human face. A system that places the will for communicating and sharing at the centre of its business model (Mackey \& Sisodia, 2013). Not long time ago, this digital version of capitalism used to be represented 
as if it had been structured around the anthropological concept of gift, a utopian inter-exchange free of lucre. These narratives, pictured the digital economy as an economic model based on altruism, more or less the latest stage of the social economy (Cockayne, 2016). Under this perspective, Uber drivers would be opting out from stable jobs and rendering their services prompted by benevolent thoughts, thus, driving thousands of miles willing to help and relieve their fellows. Airbnb landlords will be renting their rooms and houses with the selfless aim of proving the best experience to their hosts. The utopian, pseudo-hippy propaganda of the first period has presently being refuted by platform companies itself. In their corporate webpages intended for gig workers, appeal to a greedy although chic entrepreneurial desire, hiding with it the accelerated precarisation of working conditions.

Following Christian Fuchs (2016), the trade of critical data from millions of citizens should be read not only in terms of privacy rights (and thus private law) but as a question of political economy. As reported in the New York Times (Kooling, 2018) after an endless number of data breaches, user's data misuse, fake news and political manipulation all over the world, discussions about data privacy have entered the public sphere. Yet, this problematic is not new. Franck Pasquale (2015) has extensively described the algorithm economy as the producer of a 'black box society'. A system driven by opaque companies, reluctant to reveal how they manage our data, gather information and provide services that have become essential for a great majority of the population in the Global North and increasingly in the Global South.

TheBritishmedia theoristNickSrnicek(2017a,2017b) has complemented Zuboff's contribution, rebranding the aseptic definition of 'platform economy' as 'platform capitalism'. At the centre of Srnizek's definition lies the substantial transformation of the relations of production under digital platforms' algorithmic governance from companies such as Amazon or Google. These platforms, owners of the infrastructures populated by the new digital society, extract surplus value through an extensive monitorisation of the immaterial production produced on them. More recently, the notion of 'surveillance capitalism' coined in 2015 by the business scholar Shoshana Zuboff but popularised in 2018 (2015, 2018) has described the new capitalistic reality as a system based on the extraction, processing, accumulation and monetarisation of personal data, performed by computerised and automatised technologies. Christian Fuchs rather uses Dan Schiller's concept of digital capitalism (2000) to point at the integration of the so-called digital economies, within the wider frame of the global division of labour. The digital economy is, for Fuchs (2017), a dependant system, integrated with others (and traditional) capitalistic systems as the Chinese Fordist clusters or the slave system of production in the Democratic Republic of the Congo. Many others follow Lazzarato and McKinsey in highlighting the similarities of digital capitalism and the enclosure processes described by Marx (Cohen, 2019; Wittel, 2015). This plurality of definitions reflects the barely veiled conflict between system forces struggling to control the hegemony of the digital economy.

\section{The critical management perspective: what is new in the new digital corporations?}

What differentiates the business model and corporate structure of highly decentralise, externalised and globalised corporations, such as Nike, from the new digital empires? Why are we talking about a new kind of corporate power, having had incredible dominant corporations such as AT\&T, Standard Oil or Ford? In an enthusiastic defence of digital platforms (also an extraordinary seminal work on digital capitalism law), Orly Lobel (2016) outlined what she called the 10 principles of the platform corporations ${ }^{2}$. For Lobel what defines the new platform economy is the ability of digital corporations to commodify and monetise aspects and services that were previously not available in the market (such as the spare room in your house or the vacant seat in your car). What used to be considered as the guest room, now has been reframed by digital corporations as lost profit. They have found a whole new market niche, the private life. To achieve this, digital companies depend on two elements: new technologies and new social relationships with prosumers. The traditional distinction between producers and consumers became blurry in platforms such as Tinder, Facebook and LinkedIn. Other users' data, connections, or bodies, have become the appealing product to be consumed by other users, who in return have to reciprocate. The more the users, the more the product to offer and hence to consume, that has been called network-effect. New technologies may have granted corporations access to a massive market at a reduced cost. But access does not mean success. Digital corporations have had to scale, as quickly as possible, in the shortest time. Although the entry barriers are reduced, so is the benefit per product, with which reaching a critical mass of consumers is fundamental for the platforms. One of the key elements of success for these companies is that, as opposed to the traditional model, they can offer the users dynamic prices and information in real time. The vast amount of data gathered by companies such as Amazon or Netflix, allows them to offer extraordinarily accurate products, tailored to the consumers' tastes. This has a feedback effect, as satisfied users come back to the platforms providing more valuable data to the companies who are able to improve even more the products they offer. The most disruptive platforms on the market, such as Facebook, Uber, or Airbnb, do not offer products in themselves, they are defined as technology companies. They provide the basic infrastructure for prosumers to interact.

Other companies such as Netflix, Spotify or Tinder have found ways to make profit in a subscription based

\footnotetext{
The ten principles are: Economies of Scale; No More Waste; Tailoring the Transactional Unit; We Are All Capitalists Now; From Prêt-àPorter to the People's Haute Couture; Access over Ownership; Less Overhead; Reduced Barriers to entry; Pricing Precision; Dynamic Information.
} 
model. But either, as free providers or as pay-per-use services, users pay for using and consuming goods, not in order to acquire goods. Of course the well-known exception to this is Amazon, which has become not only the online market, but also a producing firm in its own right. Although Lobel describes important elements characterising the new digital corporations, she does not offer a clear image of the elements that distinguish the Silicon Valley's corporate structure from the previous model. Lobel does not mention an important aspect. While it is technically true that entry barriers are certainly low, digital businesses are not viable if they do not reach a critical mass. Reaching this critical mass means controlling or dominating a market (Culpepper \& Thelen, 2019). In short, the business models of digital platforms relies upon the achievement of a dominant position in the market, close to classic monopolies. Small or new companies find hard to reach the data power already at the hands of dominant corporations. Venture capitalist are also less likely to invest in companies competing in mature markets. Therefore, low barriers are not so in sectors such as search engines or communications. Another important element that Lobel forgot to mention is that the necessary market dominance translates into other types of power, such as political, cultural, or social (Moore \& Tambini, 2018). This also creates a feedback loop: the more the political power held by a corporation, the less legal or social barriers to dominate a market such company will find.

In a remarkable paper, Rahman and Thelen (2019) have offered a succinct and clear study detailing the characteristics of what they have called TwentyFirst-Century Capitalism. Their study analyses the managerial model prevailing during the 1950-1980, the network of contracts firm 1980-2010 and the contemporary platform business model. The managerial model of the consolidated firm, was based on four elements: dispersed shareholders with little influence over corporate governance; concentrated authority in managers and executives; vast working force mostly unionised; and legal landscape promoting welfare and antitrust regulation. This resulted in a capitalist model in which the interests of workers and managers were aligned. Large companies covering many segments of the supply chain with a huge payroll of dependent workers. This model was replaced by the neoliberal revolution of the 1980s. Speculative financial capital burst into the productive sector, demanding greater profitability and lower costs. The influence of the managers was reduced, subjected to the investors' control in what was named the shareholders revolution. Investors abandoned the previous long-term corporate strategies, based on the alliance of capital and work, to embrace a business model seeking short-term investment returns. An investing strategy defined by the authors as impatient capital. Firms outsourced and delocalise production, cut their staff, and keep only upstream aspects of the supply chain such as marketing or design. The network of contracts firm relies on a complex set of relations between firms, distributors, providers and manufactures.

According to Rahman and Thelen, the current model develops the network of contracts firm model with elements of the managerial corporation style of leadership. From the traditional corporate firms digital corporations take the concentrated leadership based on strong and personalist CEO's. Digital corporations use and optimise the decentralised, outsourced and globalised structure of the network of contracts firms. One of the disadvantages of the network of contract firms, was their weak control over outsourced downstream production. Nike has little or nearly no control over their manufactures in Thailand. Whereas, thanks to the advancement of technology, independent Uber drivers are surveilled, controlled and evaluated every second of their work time (Rosenblat, 2018). As opposed to the traditional corporation, the strong leadership of the new model does not stand on the conciliation of capital and work but in the intimate relations of investors and the CEO. Venture Capital funds have understood that in order to thrill, digital corporations need to dominate, to achieve a central position in the market. That requires long-term strategies, constant influx of funding, and probably no benefits in the short term. In other words, digital corporations such as Uber or Amazon operating in red or with almost no benefits are receiving an unprecedented amount of funding from investors in order to become a de facto monopolies (Moazed \& Johnson, 2016). New digital corporations aim not only to be successful globalised companies, but to become the critical infrastructure of everyday life. As it happened with Facebook becoming the online communications monopoly, with Amazon turning to be the Internet shop or with Google, now the gate to information (among other things). That's the spirit of contemporary platform capitalism.

For Rahman and Thelen the reason why these companies have emerged in the United States and not elsewhere responds to the particular configuration of the US' legal and political landscape. Unlike the EU with plentiful of overarching regulations, agencies and widescope policies, US legislation is fragmented. There, Federal, State and even local governments have authority over critical aspects of the new digital platforms such as privacy, labour, housing or competition. This legal and political fragmentation has been instrumentalised by digital corporations. Uber and Airbnb have acted knowing that they were breaking the law pursuing market domination. Given the scale of the violation, the characteristics of new technologies, and the unbalanced power relations between giant corporations and local authorities, regulations were poorly or not enforced. This would have been unconceivable if the companies wouldn't have had the users' enthusiastic support. Digital corporations have established unmediated close ties with their users, they are present in their lives, are part of their routines. Digital corporations have presented themselves as liberators. Fresh air in dysfunctional or/ and overpriced industries such as the taxi or hospitality. Companies like Uber or Airbnb have instrumentalised 
this intense relation with their users, mobilizing them towards more permissive legislation (Thelen, 2018).

\section{Critical legal studies and the infrastructural power}

Scholars from disciplines as different as media, culture studies, politics, economics and law have pointed out that the digital corporations' defining feature is their monopolist control over the backbone of modern political economy, or in other words, the infrastructure. The concept of infrastructure has been recently defined by Sabeel Rahman (2018) and Lina Khan (2018) after a reinterpretations of Louis Brandeis works (and acts) on antitrust. Brandeis was a US Supreme Court Justice. During the Wilson presidency (1913-1921) Brandeis helped to shape a new set of antitrust regulations that put an end to the Gilded Age monopolist corporations, modelling a progressive regulatory framework in where public interest was put above private corporations' wills. Following Brandeis, Khan and Rahman have described the current situation as a problem of private dominance over critical assets. In their opinion public institutions should assure 'social control over vital industries that provided foundational goods and services on which the rest of society depended.' (Rahman, 2018, p. 1639). Both Khan and Rahman recognize three fundamental features of infrastructural power. Khan proposes, gatekeeper power, leveraging power and informational exploitation. Rahman outlines gatekeeping power, transmission power and scoring power. The first feature, gatekeeping power, is shared by both (as well as by other relevant authors such as Lynskey (2019)). Khan and Rahman describe gatekeeper power as digital platforms' control over the arteries of contemporary commerce and communication flows. Digital corporations are not just players in the game, they have become (or wish to become) the platform or infrastructure in where the game is played. The second feature of the infrastructural power described by Khan is the leveraging power. Given the horizontal integration of platforms and their dominance over different business sectors, they can use information obtained in a particular business for their benefit in other sectors in where they are not only the board but also players. It is worth to highlight that Google was recently sanctioned in Europe $(€ 2.42$ billions) for this precise reason (Commission v. Google, 2018). As has been probed, Google manipulated its Google shopping algorithm in order to push up its products above the results of its competitors.

The third manifestation of this power is defined as informational exploitation. Khan argues that digital corporations control the data flowing on their infrastructures, providing them with a significant advantage over users, competitors or even authorities. For example, they can alter individualised prices to users, based on opaque criteria, with obvious discriminatory effects. In the same way, they can rank, hide or highlight the information given to users on their newsfeed or the webs they are visiting. This entrails risks for equality, discrimination in addition to privacy. Rahman redefines this feature as power transmission, expanding Khan's notion of informational exploitation by looking at how dominant actors are threatening net neutrality. Corporations owning the physical infrastructure of telecommunications can grant privileged access to the network to digital corporations, resulting in wider broadband with faster connections. This could end creating an unequal double speed Internet. Rahman also refers to how this power over information may have political and social consequences (as we will see soon). Finally Rahman identifies scoring power. Platforms order, hierarchise and curate information at the disposal of users through algorithms. Those algorithms have been labelled by legal scholar Fran Pasquale as black boxes. Opaque pieces of software managing worldwide data, but unaccountable to the public. These algorithms are responsible for the Facebook's newsfeed, Google searchers or Amazon product search engine. This not only affects the private sphere. Public institutions are increasingly using private software to score citizens in the welfare system, or to determine the riskability of a specific subject, in the criminal justice system. The scoring power relies on private owned algorithms, with little or none public oversight. This infrastructural power over information flows, that is the management, distribution and production of cyberspace, has been labelled by the neo-institutionalist scholar Orla Lynskey (2019) as data power. Lynskey has tracked down the politics and intricacies of the EU data protection and how this relates with relevant UE issues such as competition. Lynskey has probed how the globally exercised data power is what allows digital corporations, such as Google, to exert power over markets, communications, politics and individuals $(2019,2018)$.

\section{Digital communism: socialist and postfordists}

Surprisingly (or not) Marx has become trending among academics looking at the rising power of digital corporations. At least two contemporary currents of Marxism are aiming to explain and revert the phenomenon of digital capitalism without renouncing to the technological developments of the digital era. The first theoretical proposal focuses its discussion around the notion of digital labour. Christian Fuchs has become the most relevant referent in the theorisation of a critical economy of digital labour. This author is perhaps the one who has most clearly exposed the interdependence between different forms of digital capitalism of which the digital economy would be only a segment. For Fuchs, the development of new forms of capitalist exploitation does not imply the disappearance of the previous technologies of domination, but the superposition of new layers on previous mechanisms of capital accumulation.

In his work Digital Labour and Karl Marx (2014) Fuchs analyses six sub-models of extraction of surplus value that occur in the context of digital economies: 1) Digital slavery in the context of mineral extraction; 
2) Exploitation, original accumulation and formal subsumption of labour in hardware production industries in China; 3) Global division of labour and new imperialism in the Indian software industry; 4) Productive aristocracy in Silicon Valley; 5) Expansion of Taylorism in the provision of digital services; 6) Compensation and extraction of surplus value from the work of the users of the platform economies. Relying on the works of the communicational scholar Dallas Smyth, Christian Fuchs has extensively analysed the political economy of platforms such as Facebook and Google, concluding that their business model is based on the exploitation of digital work. Users of online platforms such as Facebook or Tinder would be not only users, but also data producers, that is, digital labourers. With each connection, with each comment, message, swap or tweet, platform companies obtain profit, involving surplus value, and therefore capital accumulation. These unpaid wages are one of the main elements explaining the success of the platform capitalism companies (Fuchs, 2016).

TreborScholz(2017)hasalsoexplored theexploitative nature of the digital labour model. Acknowledging the originality of this stage of capitalism, Scholz proposes a new frame of interpretation for the concept of exploitation, capable of rendering the gamification technics of the digital platforms. His explanation of exploitation in digital platforms is not dissociated with joy or pleasure for the digital labourers. The essence of gamification relies on the ability of digital platforms to render their labouring process as video games, fostering addictive and competitive behaviours that literally hook their 'prosumers'. Scholz has also analysed digital labour regulatory frameworks, especially from the US and how they negatively impact on worker's rights (and of course their material conditions). But what is perhaps his most interesting proposal relates to his experience as a digital workers organiser. In Ours to Hack and to Own: The Rise of Platform Cooperativism, A New Vision for the Future of Work and Fairer Internet, Scholz leads a collective book aimed to provide workers and activists with a practical toolbox towards political organisation, specifically towards the organisation and defence of digital coops (Scholz \& Schneider, 2017).

The second theoretical Marxist current is composed by the autonomous school of post-Fordist thought. Among the most outstanding authors, we can name Mauricio Lazzarato (2014), Mario Tronti (2015), Moulier-Boutang (2016), Matteo Pasquinelli (2015) or Franco Berardo 'Bifo' (2017), but also other theoreticians somewhat more distant from these proposals such as Tiziana Terranova (2014) or Nick Srnicek. It is worth to highlight Tiziana's pathbreaking role in thinking the conflict of capital and labour in the digital era. Her conceptualisation of the creative industries as free labour (2000) is still up to date. These contributions share a common interest in the Marxian 'fragment of the machines' a text that could be found in the 'Grundisse' (1993), a work that was only translated into English in 1973. The fragment is for the postfordists, a turning point in Marxian though as it announces, predicts(?), the 'informational society', the machinization, the substitution of workers by robots, and a sort of working class' collective intelligence named as 'general intellect'. Around these key elements, postfordist theorist Maurizio Lazzarato (1996) coined the concept of immaterial labour, later assumed and reformulated by many other scholars and activists. In this model, the whole society has become productive; the hegemonic productive class is the cognitariat, that is to say, the set of immaterial workers that are the core of productive relations in the information society. The capitalist Biopower has constituted extraction mechanisms capable of appropriating the cooperative work, subsuming the productive general intellect to capital. Thus, the social factory is currently hacked by capitalism, although the natural communist tendency of the productive forces is progressively exhibiting the contradictions of the capitalist model and pushing forward to its end. Matteo Pasquinelli has been specifically successful in developing an original critic to digital capitalism. As oppose to Fuchs, Pasquinelli considers that the exploitative nature of digital behemoths such as Google lies not in labour exploitation but on rent. Specifically Pasquinelli (2009) claims that digital capitalist have become the global rentiers of the common intellect.

For this reason, among others, Srnicek, Williams and more recently Aaron Bastani (2019) with his Fully Automated Luxury Communism propose to accelerate the current phase of capitalist development. They aim to precipitate the contradictions of capital, and thus achieve a digital socialist society. This new society would put at the service of the common industrial automation and algorithmic government, emancipating wage labour from the masses through universal basic income and reducing unwanted labour to the minimum extent. Some other digital socialists and Marxists are being more cautious with the latest developments of IA based technologies. Taking distance from the Italian postfordism but still sharing some of the philosophical roots, Nick Dyer-Witheford, Atle Mikkola Kjøsen and James Steinhoff (2019) questioned in their magnificent work Inhuman Power Artificial Intelligence and the Future of Capitalism the capitalist roots of IA while evaluating the limits of Marxist thought regarding new forms of automated production.

Digital Socialists raises the possibility of a new organisation of the digital economy through its planning. Digital socialists seem to ask, why don't we turn digital platforms into coops or communalise the search engines by establishing a model of economic socialism where the digital economy would play a relevant role but not a protagonist one? The postfordist approach reinterpret Leninism reframing the central role of the cognitariat in the articulation of future politics. Whereas Fuchs proposes to reorganize labour, postfordist tend to claim for its end and dissolution. The social factory, liberated from the tyranny of capitalism, and wisely directed by the general intellect incarnated in the cognitariat (and superpowerful communist AIs), will redistribute goods and richness and thus satisfying whatever 
the 'commons' may need. Each of these proposals involves different potentials and problems, which, despite their shortcomings, can offer an invaluable help in understanding the current phase of capitalist development of the digital economy.

Lastly, it is also worth to mention a group of authors that, although not strictly socialists or Marxists, have exposed the damaging consequences of digital capitalist corporations. Virginia Eubanks has been writing on the question of technology and social justice (in now mainstreamed topics such as the digital divide) for years (2012). But her latest work, Automating Inequality (2018) has brought to the light what The Guardian has popularised as the 'Digital Welfare' or the automatisation of class and race discrimination at the hands of public and private corporations. In this line Safiya Noble (2018) recently analysed the racist bias of 'neutral' algorithms, such as the Google one. The literature looking at the relation of racism and algorithms is rising, sadly, inasmuch as those technologies spread hand in hand with the privatisation of nearly every aspect of the criminal justice system, from policing to judging and managing prison population (Wang, 2018). Finally Nick Couldry and Ulises Mejias using an innovative decolonial theoretical framework, have scrutinised the colonisation (and commodification) of every single aspect of our lives by digital corporations.

\section{Conclussions}

In the beginning of this text Ihave performed a sociological approach to the question of digital capitalism. In the first place I have exposed the relevance of the phenomenon, highlighting the attention it has generated in academia, politics and society in general. Secondly, I have shown how, although there is a consensus in recognizing the importance of the event, there is no academic agreement when defining it. The second part of the work looks at three bodies of literature looking at digital capitalism. I have analysed relevant works coming from Critical Management Studies. Following influential works I have explained the new digital capitalism's business model, as well as the digital platforms' corporate structure. Then I have deepened in the works of Critical Legal Studies scholars, mostly from the United States. From this approach I have delved into what CLS scholars consider one of the digital capitalism's pillar: The infrastructural power. Finally, the article closes with a brief analysis of two Marxist currents investigating and questioning the rise of digital capitalism. The first current has been here labelled as 'socialist'. This current follows an updated but orthodox Marxist, heavily focused on wage and unwaged labour. The second current analysed, labelled here as the postfordist, takes Karl Marx Grundisse's as a departing point. This current seeks to adapt Marxist thinking to new technological and productive developments, especially with regards to automation. It is also exploring new communist horizons in highly technologized societies. The three different bodies of literature analysed here, coincide in recognising digital capitalism as a new a reality where the majority of the worldwide population inhabits, at least, part of the time. A brave new world built under the domination of digital corporations. The academic community has a responsibility towards this (not that new) problematic. For us, the task now is to resist the monstrous tech corporate power, without falling in a reductionist critique of technology.

\section{References}

Bastani, A. (2019). Fully automated luxury communism. London: Verso.

Berardi, F. B., Douglas, D., \& Szwedska, T. (2017). Warming the Algorithm and Possibilities for the Future. An Interview with 'Bifo' Berardi. Chiasma: A Site For Thought, 4(1), 12.

Braña, F. J. (2019). A fourth industrial revolution? Digital transformation, labor and work organization: a view from Spain. Journal of Industrial and Business Economics, 46(3), 1-16. https://doi.org/10.1007/s40812-019-00122-0

Brossat, I. (2018). Airbnb, la ville ubérisée. Paris: la Ville brûle.

Cockayne, D. G. (2016). Sharing and neoliberal discourse: The economic function of sharing in the digital on-demand economy. Geoforum, 77, 73-82. https://doi.org/10.1016/j.geoforum.2016.10.005

Carolan, M. (2019). Automated agrifood futures: robotics, labor and the distributive politics of digital agriculture. The Journal of Peasant Studies, 47(1) 184207. https://doi.org/10.1080/03066150.2019.1584189

Castells, M. (2010). End of millennium: The information age: Economy, society, and culture. Hoboken: Wiley.

Cohen, J. E. (2019). Between Truth and Power: The Legal Constructions of Informational Capitalism. Oxford: Oxford University Press.

Commision v. Google (2017). Case 38606 - AT.39740 Google Search (Shopping).

Corcho, R. A. (2017). La regulación de la economía colaborativa: Airbnb, BlaBlaCar, Uber y otras plataformas. Valencia: Tirant lo Blanch.

Couldry, N., \& Mejias, U. A. (2019). The costs of connection: How data is colonizing human life and appropriating it for capitalism. Redwood City: Stanford University Press.

Couldry, N., \& Mejias, U. A. (2019). Data colonialism: Rethinking big data's relation to the contemporary subject. Television \& New Media, 20(4), 336-349. https://doi.org/10.1177/1527476418796632

Culpepper, P. D., \& Thelen, K. (2019). Are We All Amazon Primed? Consumers and the Politics of Platform Power. Comparative Political Studies, 53(2), 288-318. https://doi.org/10.1177/0010414019852687 
de Graaf, G. (2017). Digital economy development in Spain. Información Comercial Española, ICE: Revista de economía, (897), 129-140. https://doi.org/10.32796/ice.2017.897.1952

Doménech Pascual, G. (2015). La regulación de la economía colaborativa. El caso Uber contra el taxi. Ceflegal. Revista práctica de Derecho, 175-176, 61-104.

Dyer-Witheford,N., Kjøsen A.M., \& Steinhoff J.J. (2019). Inhuman power: artificial intelligence and the future of capitalism, digital barricades: Interventions in digital culture and politics. London: Pluto Press.

Eubanks, V. (2012). Digital dead end: Fighting for social justice in the information age. Cambridge: MIT Press.

Eubanks, V. (2018). Automating inequality: How high-tech tools profile, police, and punish the poor. New York: St. Martin's Press.

Fuchs, C. (2011). A Contribution to the Critique of the Political Economy of Google. Fast Capitalism, 8(1), 1-24. https:// doi.org/10.32855/fcapital.201101.006

Fuchs, C. (2014). Digital Labour and Karl Marx. London: Routledge

Fuchs, C. (2016). Facebook. In Global media giants (B. Birkinbine, R. Gómez \& J, Wasko. pp. 442-458). London: Routledge.

Fuchs, C. (2017). Social media: A critical introduction. London: Sage.

Gil, J., \& Sequera, J. (2018). Expansión de la ciudad turística y nuevas resistencias. El caso de Airbnb en Madrid. Empiria. Revista de metodología de ciencias sociales, 41, 15-32. https://doi.org/10.5944/empiria.41.2018.22602

Grassegger, H., \& Krogerus, M. (2017, January 30). The data that turned the world upside down. Vice Magazine.

Hobbs, M., Owen, S., \& Gerber, L. (2017). Liquid love? Dating apps, sex, relationships and the digital transformation of intimacy. Journal of Sociology, 53(2), 271-284. https://doi.org/10.1177/1440783316662718

Janeway, W. H. (2018). Doing Capitalism in the Innovation Economy: Reconfiguring the Three-Player Game between Markets, Speculators and the State. Cambridge: Cambridge University Press.

Johannessen, J. A. (2019). Automation, Capitalism and the End of the Middle Class. London: Routledge.

Khan, L. (2018). Sources of Tech Platform Power. Georgetown Law Technology Review, 2(2), 325-334.

Klossa, G. (2019). Towards a European Media Sovereignty an Industrial Media Strategy to leverage Data, Algorithms and Artificial Intelligence. Brussels: European Commission.

Kooling, K. (2018, March 22). How Democracy Can Survive Big Data. New York Times. Retrieved from: https://www. nytimes.com/2018/03/22/opinion/democracy-survive-data.html

Lazzarato, M. (2014). Signs and machines: Capitalism and the production of subjectivity. Los Angeles, CA: Semiotext(e).

Lazzarato, M. (1996). Immaterial labor. In Radical thought in Italy: A potential politics (P. Virno \& M. Hardt, pp. 133-47).

Lobel, O. (2016). The law of the platform. Minnesota Law Review, 101(1), 87-110.

Lynskey, O. (2019). Grappling with "Data Power": Normative Nudges from Data Protection and Privacy. Theoretical Inquiries in Law, 20(1), 189-220.

Lynskey, O. (2018). The Power of Providence. Digital Dominance: The Power of Google, Amazon, Facebook, and Apple.

Lynskey, O. (2015). The foundations of EU data protection law. Oxford University Press.

Mackey, J., \& Sisodia, R. (2013). Conscious Capitalism: Liberating the Heroic Spirit of Business. Cambridge, MA: Harvard Business School Press.

Marx, K. (1993). Grundrisse. London: Penguin.

Moazed, A. \& Johnson, N. L. (2016). Modern monopolies: what it takes to dominate the 21st century economy. New York: St. Martin's Press.

Moore, M. \& Tambini, D. (Eds.). (2018). Digital dominance: the power of Google, Amazon, Facebook, and Apple. Oxford: Oxford University Press.

Morozov, E. (2013). To save everything, click here: The folly of technological solutionism. New York: Public Affairs.

Moulier-Boutang, Y. (2016). Du capitalisme fordiste au nouveau capitalisme: les filets du capitalisme cognitif, pour comprendre la guerre des codes. Capitalismo Cognitivo y Economía Social del Conocimiento. La lucha por el Código, 2 , 15

Nickerson, D. W., \& Rogers, T. (2014). Political campaigns and big data. Journal of Economic Perspectives, $28(2), 51-74$. https://doi.org/10.1257/jep. 28.2.51

Noble, S. U. (2018). Algorithms of oppression: How search engines reinforce racism. New YorK: New York University Press.

Palmer, L. (2020). Dating in the Age of Tinder: Swiping for Love?. In Romantic Relationships in a Time of 'Cold Intimacies' (J. Cartes \& L. Arocha, pp. 129-149). London Palgrave Macmillan, Cham.

Pasquale, F. (2015). The black box society: The secret algorithms that control money and information. Cambridge MA: Harvard University Press.

Pasquinelli, M. (2009). Google's PageRank algorithm: A diagram of cognitive capitalism and the rentier of the common intellect. In Deep search: The politics of search beyond Google (K. Becker \& F. Stalder, pp. 152-162). Innsbruck: Studien Verlag.

Pasquinelli, M. (2015). Italian operaismo and the information machine. Theory, Culture \& Society, 32(3), 49-68. https:// doi.org/10.1177/0263276413514117 
Rahman, K. S. (2018). Infrastructural Regulation and the New Utilities. Yale Journal on Regulation, 35(3), 911-940.

Rahman, K. S. \& Thelen, K. (2019). The Rise of the Platform Business Model and the Transformation of Twenty-FirstCentury Capitalism. Politics \& Society, 47(2), 177-204. https://doi.org/10.1177/0032329219838932

Rosenblat, A. (2018). Uberland: How Algorithms Are Rewriting the Rules of Work. Berkeley: Univ. of California Press.

Rouvroy, A. \& Stiegler, B. (2016). The digital regime of truth: From the algorithmic governmentality to a new rule of law. La Deleuziana: Online Journal of Philosophy, 3, 6-29.

Scholz, T. (2017). Uberworked and underpaid: How workers are disrupting the digital economy. Hoboken: Wiley.

Scholz, T. \& Schneider, N. (Eds.). (2017). Ours to hack and to own: The rise of platform cooperativism, a new vision for the future of work and a fairer internet. New York: OR books.

Schiller, D. (2000). Digital capitalism: Networking the global market system. MIT press.

Slee, T. (2017). What's yours is mine: Against the Sharing Economy. New York: Or Books.

Srnicek, N. (2017a). Platform capitalism. Hoboken: Wiley.

Srnicek, N. (2017b). The challenges of platform capitalism: Understanding the logic of a new business model.Juncture, 23(4), 254-257. https://doi.org/10.1111/newe.12023

Srnicek, N. \& Williams, A. (2015). Inventing the future: Postcapitalism and a world without work. Verso Books.

Sundararajan, A. (2014). Peer-to-peer businesses and the sharing (collaborative) economy: Overview, economic effects and regulatory issues. Written testimony for the hearing titled The Power of Connection: Peer to Peer Businesses.

Sundararajan, A. (2016). The sharing economy: The end of employment and the rise of crowd-based capitalism. Cambridge: Mit Press.Thatcher, J. (2017). You are where you go, the commodification of daily life through 'location'. Environment and Planning A: Economy and Space, 49(12), 2702-2717. https://doi. org/10.1177/0308518X17730580

Thelen, K. (2018). Regulating Uber: The politics of the platform economy in Europe and the United States. Perspectives on Politics, 16(4), 938-953. https://doi.org/10.1017/S1537592718001081

Terranova, T. (2000). Free labor: Producing culture for the digital economy. Social text, 18(2), 33-58.

Terranova, T. (2014). Red stack attack. In \#Accelerate: The Acceleraonist Reader (Robin Mackay and Armen Avanessian, pp. 379-399). Falmouth: Urbanomic.

Thieulin, B. (2019). Towards a European digital sovereignty policy. Opinion of the Economic Social and Environmental Council presented rapporteur On behalf of the Section for European and International Affairs. Paris: Economic Social and Environmental Council

Tronti, M. (2015). Teologia politica contro la dittatura del presente. Rivista di politica, 3(3), 111-115.

U.K. Parliament (2019). Disinformation and 'fake news' report. Sub-Committee launched on 2 April 2019 to continue work on Disinformation.

U.S. House of Representatives. (2019). Hearing: Online Platforms and Market Power. Subcommittee on Antitrust, Commercial, and Administrative Law (Committee on the Judiciary)

Vaidhyanathan, S. (2018). Antisocial media: How Facebook disconnects us and undermines democracy. Oxford: Oxford University Press.

van Dijck, J., Nieborg, D. \& Poell, T. (2019-8?). Reframing platform power. Internet Policy Review, 8(2). http://doi. org/10.14763/2019.2.1414

Wang, J. (2018). Carceral capitalism. Cambridge: MIT Press.

Wingfield, N. (2017, March 12). Miscue Calls Attention to Amazon's Dominance in Cloud Computing. The New York Times. Retrieved from: https://www.nytimes.com/2017/03/12/business/amazon-web-services-outage-cloudcomputing-technology.html

Wittel, A. (2015). Digital Marx: Toward a political economy of distributed media. In Marx in the Age of Digital Capitalism (C. Fuchs, pp. 68-124). Leiden: Brill.

Zuboff, S. (2015). Big other: surveillance capitalism and the prospects of an information civilization. Journal of Information Technology, 30(1), 75-89. https://doi.org/10.1057\%2Fjit.2015.5

Zuboff, S. (2018). The age of surveillance capitalism: The fight for a human future at the new frontier of power. New York: Public Affairs. 